\title{
Participation of the Northern Indigenous Peoples in the Management of the Russian Arctic Territories and Its Legal Protection
}

Elena Gladun ${ }^{1}$, Gennady Chebotarev ${ }^{2}$

\begin{abstract}
The paper is an overview of the participation of the northern indigenous peoples in the public management of the Arctic territories in Russia. Different forms of participation are described, and most attention is paid to the co-management of the governments and the indigenous peoples when their mutual aim is protecting the Arctic and its natural landscapes in the period of extensive industrial development.

The principle objective of the paper is to analyze the international and national legal regulations and to show some effective legal mechanisms through which participation can be developed in Russia.

The authors study definitions of participation, the main international principles of participation and give a deep analysis of the legislation of the Russian Federation, which provides the framework for indigenous participation. Much attention is paid to the legislation of the federative regions of Russia which are inhabited by the northern indigenous peoples. Mostly the authors study the example of the Yamalo-Nenets Autonomous Area, the Arctic area of Russia with the biggest gas reserves, inhabited by the Nenets.

The first conclusion made in the paper is that the Arctic countries must not only prioritize the exploitation of rich Arctic resources, but also be aware that the Arctic is primarily the home and the area of the traditional lifestyle and occupations of the northern indigenous peoples who have lived there for a long time. The northern indigenous peoples are interested in cooperation with the governments according to their traditional values and knowledge; they want to be involved in the decision-making process and management of their territories and resources.
\end{abstract}

1 Associate professor, Tyumen State University, Tyumen, Russia.

2 President, professor, Tyumen State University, Tyumen, Russia. 
The second conclusion is that a patchwork of federal laws regulating indigenous issues in Russia does not grant any special rights that let the northern indigenous peoples participate in the decision-making process concerning the lands and resources in the Arctic areas. The federal government mostly implements the concept of paternalism but not the concept of participation. The federative regions in their regulations provide considerably more opportunities for participation. However, the regions are quite restricted by the federal legislation. The regulations are fragmentary on both the federal and the regional levels, there is no system of public authorities providing for consultation, cooperation, agreements and other forms of indigenous participation. Moreover, in Russia there is very little experience in the realization of the participation of the Arctic territories and resources.

The third, and most important, conclusion is that participation in the management of the Arctic territories should become a new element of the Russian Arctic policy. From this perspective it is necessary to ratify and sign two international documents - Indigenous and Tribal Peoples Convention No. 169 and the United Nations Declaration on the Rights of Indigenous Peoples - and to incorporate the basic principles of participation into the Russian federal legislation. Also it is vital to establish a specialized federal body on indigenous issues with a special focus on the northern indigenous peoples. Lastly, the legal and administrative capabilities of regions and local authorities should be increased, and the regional and local bodies should be vested with the power to involve indigenous peoples in the management of the northern territories.

Key words: participation, indigenous peoples, the Arctic, legislation, public authorities

\section{Introduction}

Indigenous peoples have inhabited the Arctic for thousands of years. The proportion of indigenous peoples is estimated to be about 10 percent of the total population living in the Arctic areas. There are over 40 different ethnic groups living in the Arctic (Arctic Info 2014). In Russia the northern indigenous peoples include the Aleuts, Koryak, Eskimos, Chukchi, Evenks, Yakuts, Yukagirs, Dolgan, Selkup, Nanai, Khanty, Mansi, Nenets, Saami and others (Arctic Info 2014). The northern indigenous peoples inhabit more than 20 federative regions (called "subjects of the Russian Federation") of the Russian Federation, including the Republic of Sakha (Yakutia), the Kamchatka Territory, the Krasnoyarsk Territory, the Khabarovsk Territory, the Magadan Region, the Murmansk Region, the Chukotka Autonomous Area, the Nenets Autonomous Area, the Khanty-Mansi Autonomous Area, Yugra and the Yamalo-Nenets Autonomous Area (Batyanova et al. 2009). They occupy remote territories, including the polar areas and islands in the Arctic Ocean. The proximity of the Pole and the Arctic Ocean determine the climate and nature of 
these areas, and also their landscape, which mostly consists of tundra and foresttundra. Vast areas are covered by mountains and bogs, and there are many lakes and rivers. Fog, strong winds, long winters, permafrost and scanty vegetation are only a few of the geographic features that illustrate the challenges faced by people living in these areas (Abryutina and Chashchin 2004). The traditional activities of the northern indigenous peoples include reindeer-breeding, hunting, fishing, seahunting and gathering (Krupnik 1993).

The northern indigenous peoples use the environment and natural resources for their living sustainably. They have responded to major climatic and environmental changes by altering group sizes, relocating and being flexible with seasonal cycles in hunting or employment (Park 2008). The northern indigenous people are bearers of valuable and unique knowledge about the Arctic landscapes and possess traditional values, culture and skills (Arctic Monitoring and Assessment Programme 2004).

On the other hand, the Arctic is one of the main resource-rich regions on the planet, and non-traditional economic activities in the northern territories are on the rise in all Arctic countries. Prioritizing the resource use in the Arctic countries, the governments should be aware that the Arctic is primarily the home and area of life, economic and cultural well-being of indigenous peoples who have lived there for a long time. It has become obvious that the northern indigenous peoples are interested not only in the compensation for loss and environmental harm, they do not only demand protection of their rights and interests from the governments, but they want to be involved in the decision-making process and management of their territories and resources. Moreover they are willing to participate in the Arctic resource use and protection according to their traditional values and knowledge. That is the main reason why the governments of the Arctic countries (Canada, USA, Finland, Russia and others) are trying to find the most effective forms of indigenous participation in the Arctic issues.

The economic policy of Russia in the new century focuses on the exploration of mineral resources in the northern Arctic territories and the development of the Arctic energy resources (Foundations of Russian Federation Policy ... 2009). Today indigenous peoples of the Russian North face threats from intensive mineral, oil, and gas development, and the resulting conflicts have affected all aspects of their life, including social, cultural and spiritual integrity.

The objective of this paper is to analyze the international rules and the Russian legislation on indigenous issues and to discuss if the northern indigenous peoples of Russia have moved forward in their struggle for rights, mainly for their right to participate. The research questions can be formulated as follows: is there a legal framework in Russia which makes it possible to implement effective mechanisms for the indigenous peoples to participate in the decision-making and management of the Arctic territories and resources, and what improvements can be suggested 
to the legislation in this realm? The answer to this question is vital for the Russian indigenous peoples inhabiting the Arctic territories, who face the problems of using their lands because of the industrial development there. For example, the nomadic way of life in the Arctic is under threat from the effects of climate change, making the tundra increasingly unpredictable, and from the discovery that the Yamal peninsula contains the largest gas reserves on the planet. In fact, Yamal Nenets do not participate to a large extent in the decisions about using their traditional lands, and priority is mostly given to the industrial, but not the traditional development.

The strategy employed for this research includes literature and terminology analysis, study and analysis of international documents, Russian federal and regional laws. Also the authors used sociological research methods, such as case studies, surveys and interviews with indigenous peoples and representatives of public authorities.

Part II of the paper provides a revision of the publications and research on the participation of indigenous peoples in different countries in the latest years and considers the relevant international law on indigenous participation, focusing mostly on the International Labor Organization Convention (No. 169) and the United Nations Declaration on the Rights of Indigenous Peoples. Part III describes the constitutional and legal framework for indigenous participation in public decision-making and finally discusses their possibilities to participate in the use and protection of the Arctic lands and resources, to represent their interests and consent in the public authorities. The authors focus on gaps and controversies of recent federal and regional laws, regulating participation and its specific form - co-management. In Part IV there is a classification of the existing forms of participation and the analysis of terms related to participation and examples of their involvement into the Russian legislation. Finally in Part V the paper attempts to propose some steps for the Russian legislation and public authorities which are needed in order to provide for the participation of the Russian indigenous peoples in the Arctic issues.

\section{International discussion on the participation of indigenous peoples in the Arctic issues, international regulations on indigenous participation}

In the last 20 years a growing body of scholarly literature on indigenous peoples has appeared. Research from all over the world discusses the concerns and demands of indigenous peoples, forges indigenous identity and knowledge and shares experience and information regarding the success that indigenous peoples have achieved in protecting their rights and interests. Much attention in the papers and discussions is paid to the participation of indigenous peoples in the management and disposal of their lands, territories and resources. At the end of the $20^{\text {th }}$ century the authors wrote more on cultural participation or minimal self-determination (Shut- 
kin 1991), political participation (Turpel 1992; Holland and Blackburn 1998) and participation in sustainable development (Ghai and Vivian 1992; Hornstein 1999; Sanford 2002).

Different issues of indigenous participation in public management have been discussed by Grazia Borrini-Feyerabend, who is a well-known specialist in the politics and practice of conservation and development. Her works focus on the governance of natural resources and protected areas, in particular with reference to history, equity and rights, indigenous peoples and local communities. We have based the results of our research on her works Evaluating Governance: A Handbook to Accompany a Participatory Process for a Protected Area (Abrams, Borrini-Feyerabend et al. 2003) and "From Guns and Fences to Paternalism to Partnerships: The Slow Disentangling of Africa's Protected Areas" (Borrini-Feyerabend and Sandwith 2003). Borrini-Feyerabend was one of the first who used the terms "collaborative management" and "co-management" related to the participation of indigenous peoples (Borrini-Feyerabend 1996; Borrini-Feyerabend et al. 2000).

The transformation of indigenous interests is illustrated in the newest literature on the related topics. Most debates are now about the participation of indigenous peoples in the management of their lands and resources and in the decisionmaking process. For example, participation in the decision-making process and co-management of Native Americans and Canadian aboriginal peoples is observed in Betsy Baker's paper (Baker 2013). A big concern of indigenous peoples is the participation in managing the Arctic resources. This issue has been on the rise since the beginning of the 2000s (Smith et al. 1997; Damas 2004; Park 2008; Fow 2012). A deep analysis of indigenous rights in the Russian Federation was suggested by Gail Osherenko in her article "Indigenous Rights in Russia: Is Title to Land Essential for Cultural Survival?" (Osherenko 2001). The author believes that the development of indigenous rights regarding lands and resources in Russia diverges sharply from the development of indigenous rights in the Canadian North and Alaska. Much has changed since the beginning of the $21^{\text {st }}$ century in Russia, and Russian researchers have triggered a vast range of issues about indigenous participation in public affairs (Andrichenko 2005; Kharyuchi 2009; Kryazhkov 2013, 2014).

Some international documents pay special attention to the relationship between the natural environment, sustainable development and the cultural, social, economic development of indigenous peoples. The United Nations has served, and still serves, as the forum most often utilized by indigenous peoples for these purposes. For example, Agenda 21 requires states to promote the role and participation of indigenous peoples and local communities (Agenda 21 1992, art. 26.3). The involvement of indigenous people and their communities at the national and local levels in resource management and conservation strategies is suggested in other relevant programs of Agenda 21 (Agenda 21 1992). 
The most meaningful international documents focusing on the rights of indigenous peoples are the Convention Concerning Indigenous and Tribal Peoples in Independent Countries (Indigenous and Tribal Peoples Convention No. 169, 1989) and the UN Declaration "On the Rights of Indigenous Peoples" (DRIPS 2007). Regulating the rights and fundamental interests of indigenous peoples and the actions of governments, the documents also play a significant role in establishing participation principles and mechanisms. The analysis of the documents lets us formulate a special form of indigenous participation - co-management of traditional territories and resources which include:

- the right to participate in the use, management and conservation of their lands and resources;

- the right to determine and develop priorities and strategies for the development or use of their lands and other resources. To guarantee this right governments must obtain the free and informed consent of indigenous peoples prior to the approval of any project affecting their lands or territories and other resources, particularly in connection with the development, utilization or exploitation of mineral, water or other resources (DRIPS 2007, art. 32);

- the right to control the territories of their living and economic activities;

- the right to participate in decision-making through their own representatives and institutions;

- the right to consult and cooperate with the governments.

The goal of the Arctic states, exploiting natural resources in the northern territories, is to maintain a balance between the industrial development of the northern territories and sustainable development of the indigenous peoples. Their effort should be based on a comprehensive and reasonable approach and should assume a participation concept.

Some Arctic states have ratified Convention No. 169 and signed DRIPS (Norway, Denmark; (NORMLEX, Information System on International Labour Standards). Although not every nation-state has adopted laws that allow for such participation, some do have such laws. For example, in the United States, indigenous peoples may use the National Environmental Policy Act (NEPA) to submit comments to the relevant federal agency and then ensure that the agency at least considers the community’s concern (42 U.S.C. $\$ \$ 4321-4370,2006)$. In this manner, American indigenous communities can ensure that they have an opportunity to comment on projects that could potentially contribute to increased greenhouse gas emissions and, as a result, climate change (Abate and Kronk 2013). 


\section{Legal framework for the participation of the northern indigenous peoples in the Russian Federation}

The Russian Federation has not ratified Convention No. 169 and has not signed DRIPS yet. Formally, Russia has no legally binding obligation to implement the mechanisms of participation into its national legislation. Nevertheless, the necessity to accept those documents has been discussed several times in the State Duma of the Russian Federation. Indigenous peoples and their organizations often urge the State to adopt a more systematic approach and to ensure the implementation of DRIPS. ${ }^{3}$ Many researchers in Russia agree that indigenous peoples are a quite specific stakeholder in resource decision-making, because their traditional way of life is based on a deep relationship with nature; lands and resources are part of their identity. For example, Liudmila Andrichenko emphasizes that issues of legislative division of powers between different levels of government in the protection of the native habitat and the traditional way of life of indigenous peoples have become significant for the Russian government in recent years (Andrichenko 2005).

In its Article 15(4) the Russian Constitution underlines that the universally recognized norms of international law and international treaties and agreements of the Russian Federation shall be a component part of its legal system (Constitution of the Russian Federation 2014). Even non-ratified international documents on indigenous peoples have much influence on Russian legislation and governmental authorities' functions. Indigenous peoples in Russia have gained some constitutional and legislative support: the Russian Constitution guarantees the rights of indigenous peoples "in accordance with generally recognized principles and norms of international law" (Constitution of the Russian Federation 2014, art. 69) and shares the responsibility between federal and regional governments for "the protection of traditional living habitat and of traditional way of life of small ethnic communities" (Constitution of the Russian Federation 2014, art. 72). Under Article 72 of the Constitution the federal government has the responsibility and jurisdiction to regulate and protect the rights of indigenous peoples, and the federative regions (subjects) must bring their laws into conformity with federal law.

The Concept for the Sustainable Development of Indigenous Peoples of the North, Siberia and the Far East of the Russian Federation is the key document determining the main principles of Russian national policy towards the indigenous

3 For more information see "On Ratification of the Convention Concerning Indigenous and Tribal Peoples in Independent Countries." No. 169 (1989 г.): Materials of the Parliament Hearings. 1995. In K. Arackchaa. Korennye Narody: Mezhdunarodnoe i Nacionalnoe Pravo [Indigenous Peoples: Domestic and International Law]. Moscow; The Round Table About Ratification of the Declaration No. 169 in Russia was organized in Moscow by the Federation Council in November 2006. More information can be found at the official website of the Federation Council of the Russian Federation. Available at http://mobile.council.gov.ru/press-center/news/26049/; Ратификация Конвенции № 169 - назревшая необходимость. Available at http://severcom.ru/ analytics/item11-3.html/. 
peoples of the North. The main objective of the policy is to strengthen their social and economic potential, to protect the traditional environment, traditional lifestyle and cultural values with governmental support as well as through mobilization of their internal resources (Rasporyazhenie Pravitelstva 2009). As one of the principles it states the participation of indigenous peoples and their representatives and associations in making decisions when natural resources are explored and used in traditional habitats and the areas of traditional economic activities. Unfortunately, the Concept does not suggest any legal mechanisms to implement participation principles.

Federal legislation implementing the constitutional provisions about indigenous peoples consists of the Federal Law "Guarantees of Rights of Indigenous Peoples in the Russian Federation" (GRIPRF 1999), the Federal Law "Territories of Traditional Resource Use of the Indigenous Peoples of the North, Siberia and Far East of the Russian Federation" (O Territoriah 2001) and some rules and regulations in the specific laws such as the Land Code (Zemelnyi Kodeks 2001), the Water Code (Vodnyi Kodeks 2006) and the Forestry Code (Lesnoi Kodeks 2006).

GRIPRF elaborates constitutional norms, and at one point it established the right of indigenous peoples to participate through their representatives in the process of decision-making with state and local authorities concerning their habitat, traditional lifestyle and employment, environmental protection (GRIPRF 1999, art. 8, part 5). This law was adopted as the main act regulating indigenous peoples' participation in decision-making; however, the procedures for such participation have not been developed yet. The Land Code of the Russian Federation confirms the right of indigenous peoples to use agricultural land "in order to preserve and develop their traditional way of life, economics, management and crafts" (Zemelnyi Kodeks Rossiiskoi Federatsii No. 136-FZ 2001, art. 68, 78, 82). The rights of indigenous peoples to the priority use of natural resources are also provided by the Forestry Code of the Russian Federation (Lesnoi Kodeks Rossiiskoi Federatsii No. 200-FZ 2006, art. 30) and the Water Code, which sets the right to use water objects in traditional territories for traditional occupations (Vodnyi Kodeks Rossiiskoi Federatsii No. 74-FZ 2006, art. 3, 54). According to Article 19 of the Federal Law "Hunting and Preservation of Hunting Resources", hunting for supporting the traditional way of life and occupation is free (does not require a permit) if hunting resources are used for personal needs (Federalnyi Zakon No. 209-FZ 2009).

Still, the federal legislation of the Russian Federation does not match to a large extent the international rules on indigenous peoples and their rights. Vladimir Kryazhkov underlines some factors to illustrate that not all rules regulating the right to participation have been implemented in Russia for the last 10-12 years (Kryazhkov 2014).

First of all, the representation of indigenous peoples in the state and local authorities is not guaranteed by the federal laws. Before 2004 indigenous peoples 
in Russia enjoyed the right to participate in public management under GRIPRF. For example, the representation of indigenous peoples through quotas in political, legislative and executive systems was obligatory; also the indigenous communities exercised some local powers. In 2004 many norms of this federal law were repealed, and the existing legal instruments do not give indigenous peoples the rights to express their opinions and free and informed consent prior to the approval of projects affecting their territories. The development, utilization or exploitation of mineral resources is regulated without the concern and consent of the northern indigenous peoples, and the only right which they enjoy now under federal laws is the right to compensation.

Secondly, prior to 2004 indigenous peoples could be represented in local legislative and executive bodies through quotas which were regulated by the regional laws. In 2004 the state regions were deprived of this power, and the regulations were repealed from all regional laws. This amendment leaves indigenous peoples unable to participate in decision-making and to work in conjunction with the governments on the matters which would affect their lands and resources.

Thirdly, the northern indigenous peoples sometimes do not have an opportunity to cooperate and consult with public authorities because in the Russian legislation there is no special model of local government projected for settlements of the northern indigenous peoples, who live in small communities in sparsely populated areas and have to travel long distances if they need to participate in discussions or other forms of decision-making processes (Kryazhkov 2013).

Lastly, there is no special authority focusing on the northern indigenous peoples' issues on the federal level. The State Committee of Northern Affairs was abolished in 2000 by the Presidential Decree. Its functions were transferred to the Ministry of Economy and Trade and to the Ministry on the Affairs of the Federation, Migration and National Policy. By mid-2001 these ministries had not established any administrative capacity to work with indigenous peoples of the North (Towards a New Millennium 2002). Now the issues of development and implementation of national policies and legal regulation of indigenous peoples are vested in the competence of the Ministry of Culture ${ }^{4}$; also the indigenous issues are considered by the Committee of Nationalities in the State Duma and the Committee of Federation, Regional Policies and Local Government and Northern Affairs in the Federation Council. ${ }^{5}$ These authorities, in practice, take very little effort to involve indigenous peoples in joint decision-making or to obtain their free, prior and informed consent before adopting and implementing legislative or administrative measures that may affect them as is recommended by the UN Declaration (DRIPS 2007, art. 32).

4 The official website of the Ministry of Culture of the Russian Federation. Available at http:// mkrf.ru/en/ministerstvo/.

5 The official website of the Federation Council of the Russian Federation. Available at http:// council.gov.ru/about/reference/6065/. 
Three important conclusions can be made here.

(1) Very few rights to participation of indigenous peoples are recognized in the federal legislation of Russia, and mostly there are rights to use lands and natural resources for their traditional activities and traditional way of life.

(2) No special rights of indigenous peoples established in the federal legislation give them the opportunity to participate in the decision-making process concerning the lands and resources. In its policy and legal regulations towards indigenous peoples the federal government implements the principles of paternalism but not the principles of participation. It does not guarantee the right to management and conservation of their lands and resources; the right to determine and develop priorities and strategies for the development or use of their lands and other resources; and the right to control territories of their living and economic activities.

(3) There are no special federal laws under which the northern indigenous peoples can make decisions about the use and protection of the Arctic territories and resources. Some experts believe that modern Russia has a less articulated and responsive policy toward its northern territories, where the indigenous population constitutes a significant part (Yarovoy et al. 2013).

\section{Existing forms of indigenous participation and their implementation in the legislation of the Russian northern regions}

For the purposes of this paper different terms and concepts have been analyzed to understand and describe the participation of indigenous peoples in the management of the Arctic territories. Some authors use the term participation, which is understood as organized efforts to increase control over resources and regulative institutions in given social situations, on the part of groups and movements of those hitherto excluded from such control (UNRISD 1979). More generally participation is described as a process through which stakeholders influence and share control over development initiatives and the decisions and resources that affect them (World Bank 1996). In relation to indigenous peoples, participation can be defined as the fundamental right which lets them fully and effectively participate in the determination of the decisions which affect their lives (African Charter for Popular Participation in Development and Transformation 1990). The example of the Yamalo-Nenets Autonomous Area can show that some northern regions of Russia achieve a certain level of indigenous participation in their territories. The Statute of the Yamalo-Nenets Autonomous Area (Ustav (Osnovnoi Zakon) Yamalo-Nenetskogo Avtonomnogo Okruga 1998) guarantees the right of indigenous peoples to participate in the work of regional authorities and local governments according to their national traditions and customs. Public authorities are obliged to take into account 
the indigenous peoples' opinions when dealing with issues that affect their interests (Ustav (Osnovnoi Zakon) Yamalo-Nenetskogo Avtonomnogo Okruga No. 56-ZAO 1998, art. 12). The Statute of Chukotka Autonomous Area states: "The bills directly affecting the rights and interests of indigenous peoples are discussed and adopted by the Duma with the participation of Chukotka regional non-governmental organization 'Russian Association of Indigenous Peoples of the North"' (Ustav Chukotskogo Avtonomnogo Okruga 1997).

There have always been different forms of indigenous participation in public affairs. In the literature the following forms of interaction between the governments and indigenous peoples are described: consultation, cooperation, collaborative management or co-management (McCay and Acheson 1987; Gray 1989; Berkes et al. 1991; Borrini-Feyerabend 1996; Pomeroy and Berkes 1997; Rusnak 1997; Stevens 2004). The same forms of participation are sometimes implemented in the northern regions of Russia. For example, the Law "State Support to Indigenous Peoples, to their Communities and the Northern Organizations Involved in Traditional Occupations in the Territory of Yamalo-Nenets Autonomous Area" (Zakon YANAO No. 114-ZAO 2005) requires that in cases where industrial development takes place on the territory of indigenous peoples, the public authorities must inform the indigenous peoples about it and organize consultations with their representatives and communities, also public authorities provide for making legal agreements between indigenous peoples and industrial companies, especially those which develop mineral and energy resources (Zakon YANAO No. 114-ZAO 2005, art. 5). The law also grants the indigenous communities the right to participate in the development of special regional programs and in control over their execution (Zakon YANAO No. 114-ZAO 2005, art. 7).

The tendency of the recent 20 years is to speak about participation in the form of co-management. Co-management of natural resources (also cooperative, collaborative, joint, mixed, multi-party or round-table management) is a situation in which two or more social actors negotiate, define and guarantee amongst themselves a fair sharing of the management functions, entitlements and responsibilities for a given territory, area or set of natural resources (Borrini-Feyerabend et al. 2000).

Co-management. is an institutional arrangement between the public authorities and indigenous peoples in which the responsibility for resource management, resource use or conservation and economic development is shared between governments and indigenous groups; a sharing of decision-making; shared information, consultation with indigenous peoples and their participation. Often in the process of co-management government, indigenous and industrial companies enter into formal agreements specifying their respective rights, powers and obligations with reference to environmental conservation and natural-resource development. 
In Russia the concept of co-management is quite new. In theory it has been discussed by some researchers (Kryazhkov 2013), but there is no authoritative definition of it. Sergei Kharyuchi, ex-chair of the Russian Association of Indigenous Peoples of the North (RAIPON), describes a specific type of co-management - environmental or natural-resource co-management and defines it as a collaborative decision-making of the government and indigenous peoples for the protection of their native habitat and traditional way of life (Kharyuchi 2009, 88). In the Russian legislation the term "co-management" is used neither in the federal nor in the regional legislation.

Co-management should be understood more generally than consultations of public authorities with indigenous peoples, a formal partnership. It should be the modern form of participation which combines the involvement of indigenous peoples in the process of decision-making, sharing authorities between indigenous peoples and government bodies over the issues of territory and resource development and use. True co-management requires involvement in policy formulation, planning, management and evaluation (Stevens 2004).

We share the opinion of Gerret Rusnak, who thinks that co-management involves the change from a system of centralized authority and top-down decisions to a system which integrates local and state-level management in arrangements of shared authority, or at least shared decision-making (Rusnak 1997). Co-management includes specific agreements, participation, information and analysis and decision-making structures.

There is no single model of co-management in Russia but some northern regions try to implement its separate instruments, including the following.

Co-management boards: The Law "Protection of Traditional Habitat and Traditional Way of Life of Indigenous Peoples of the North in Yamalo-Nenets Autonomous Area" (2006) requires an obligatory joint decision-making process by state authorities, local-government bodies, companies, and indigenous peoples aiming at economic, social, environmental, organizational, legal and other objectives in order to preserve territories which indigenous peoples have historically occupied and which are important for their sustainable development. Under this law, the autonomous area's authorities are responsible for the establishment of indigenous councils which are included in executive authorities (Zakon YANAO No. 49-ZAO 2006).

Quota allocations in the legislative authorities: In the Duma of the KhantyMansiysk Autonomous Area the Assembly of the Northern Indigenous Peoples has been functioning for more than 15 years, and it has a special legal status. Three members of the Assembly are elected directly from the aboriginal population for a single-member constituency (Ustav (Osnovnoi Zakon) Khanty-Mansiiskogo Avtonomnogo Okruga - Yugry No. 4-oz 1995, art. 27, 49; Zakon KHMAO No. 76-oz 2001, art. 17). In the Sakhalin Region the Institution of the Northern Representatives is established in the Duma, its members are elected at the Congress of In- 
digenous Peoples, and the Institution functions as a permanent professional body in the regional legislature (Ustav Sakhalinskoi Oblasti 2001; Zakon Sakhalinskoi Oblasti No. 463 2003). Three representatives of indigenous peoples and the chairman from the small-numbered indigenous peoples are elected to the Duma of the Yamalo-Nenets Autonomous Area (Ustav (Osnovnoi Zakon) Yamalo-Nenetskogo Avtonomnogo Okruga No. 56-ZAO 1998, art. 42, 45).

Designing, administering, monitoring research programs: The law of the Yamalo-Nenets Autonomous Area grants the indigenous communities the right to participate in the development of special regional programs and in the control over their execution (Zakon YANAO No. 114-ZAO 2005, art. 7).

Regulating commercial activities: In the Republic of Sakha (Yakutia) within the territories of historic settlements of indigenous peoples the transport roads, infrastructure and economic activities are regulated with consideration of the special needs of indigenous peoples (Zakon Respubliki Sakha (Yakutia) No. 349-III 2004).

Joint coordinating committees: In some federative regions, special committees and commissions are created that are in charge of all affairs of the northern peoples. These committees function either as part of the legislature (in the Republic of Sakha (Yakutia) and the Nenets and Chukotka Autonomous Areas) or as part of the executive branch (in the Kamchatka and Krasnoyarsk Territories and the Nenets and Yamalo-Nenets Autonomous Areas). In some regions independent authorities of indigenous peoples are affiliated with executive authorities of the region (e.g., the Council of Elders in Kamchatka Territory and Nenets Autonomous Area, the board of indigenous representatives in Krasnoyarsk and Khabarovsk Regions, Murmansk Region, Yamalo-Nenets Autonomous Area) (Kryazhkov 2013, 81).

Equally-shared decision making: The Yamalo-Nenets Law "On Reindeer Breeding" (Zakon YANAO No. 46-ZAO 1998) sets up the main requirements for reindeer protection from industrial development, development of main transport routes, pipelines, communications and power lines in the territory of the autonomous area. All requirements and responsibilities for industrial companies are established jointly by the executive authorities, local government authorities and public indigenous organizations (Directorate of the UNEP/GEF 2009). Another example is the case of the Sakhalin Energy Company, which interacted with the local society of indigenous peoples in the Sakhalin Region in 2010-2012 and got their free, prior and informed consent before using the lands (Sulyandziga 2011a).

Authority to make recommendations for action: In the Yamalo-Nenets Autonomous Area there is a specialized body which deals with the indigenous issues the Department of Indigenous Peoples' Affairs (Postanovlenie Pravitelstva YANAO No. 90-P 2010). The scope of the Department's functions is rather big - from the protection of indigenous peoples' rights to assistance in organizing factories and trading stations in the Far North. Some functions of the Department are aiming at the promotion of co-management in the Area. For example, the Department 
provides most favorable conditions for traditional activities of indigenous peoples, assists in the interaction between indigenous peoples and their communities and oil and gas companies operating in the Yamal territories. Under the Department's supervision the councils of indigenous peoples are established, and these councils decide many issues about land and resource use, about certain conditions for industrial development of the territories, compensations from the oil and gas companies and others. All rules and regulations concerning indigenous peoples and their traditional way of life are to be considered in the Department.

\section{Conclusion - the measures that can be undertaken in Russia to ensure the effective participation of the northern indigenous peoples}

The ideas of participation of the northern indigenous peoples in the management of their traditional territories and resources have been discussed worldwide for the last twenty years. Two international documents - Convention No. 169 and UN Declaration on the Rights of Indigenous Peoples set the main principles and mechanisms of participation.

It would be wrong to say that there are no legal fundamentals that allow the northern indigenous peoples in Russia to participate in the management of the Arctic territories. For example, even if the Constitution of the Russian Federation has not included the right of indigenous peoples to participation, nevertheless it guarantees the right of all people to participate in state affairs both directly and through their representatives, to exercise their power directly and also through the bodies of state power and local government (Constitution of the Russian Federation 2014, art. 3, 5, 32, 130).

Rodion Sulyandziga, the director of the Centre for Support of Indigenous Peoples of the North believes:

Federal authorities today need a new paradigm and new political will in the relations with aboriginal peoples, they have to initiate the process of negotiations and agreements, to create a legal framework for the implementation of a model of collaborative decision-making. It will be a new way of managing and controlling vast territories which have geopolitical and resource value. Moreover, this new model of relationship will allow indigenous peoples to develop their community and economics, to participate in co-management. Co-management should become a new element of the state policy. All issues of gaming, fishery, forest and subsoil use, environmental protection should be discussed in comanagement processes (Sulyandziga 2011b). 
Co-management is the most effective form of indigenous participation where governmental agencies, local communities and resource users, nongovernmental organizations and other stakeholders negotiate the authority and responsibility for the management of traditional lands or natural resources.

The analysis of the Russian federal and regional legislation and practice shows that there is a certain legal framework for participation, but it is hardly implemented on the federal level.

The federative subjects (regions) of the Russian Federation are just trying to adopt participation procedures in their territories. The regional and municipal bodies of the Yamalo-Nenets Autonomous Area, for example, use all existing legal instruments to involve indigenous peoples in the co-management of the territories and resources. However, the opportunities available to the regions in this regard are quite limited by the federal legislation. At the federal level, on the contrary, there is very little initiative to involve the northern indigenous peoples into the decision-making process. For example, no instruments have been developed for free, prior, and informed consent for the use of lands traditionally occupied by indigenous peoples, as required by the UN Declaration. We can hardly speak of a well-developed participation process in the Arctic areas of Russia. The regulations on participation are fragmentary both in the federal and regional legislations, there is no system of public authorities involved in participation, and, moreover, they have very little experience of exercising participation.

Thus, the objective of Russia is to create a comprehensive and reasonable approach to maintaining a balance between the intensive industrial development of the Arctic and sustainable development of the northern indigenous peoples. This approach can be called co-management. The certain steps should be followed:

- to ratify and sign two international documents: Indigenous and Tribal Peoples Convention No. 169 and United Nations Declaration on the Rights of Indigenous Peoples and to incorporate international norms on participation and comanagement into national legislation. In this case it will be necessary to amend federal laws on indigenous peoples. The notion of "co-management" should be included into the Concept for the Sustainable Development of Indigenous Peoples of the North, Siberia and the Far East of the Russian Federation. More attention in the Concept should be paid to the Arctic territories and the role of indigenous peoples in their management and sustainable development;

- the Federal Law "Guarantees of Rights of Indigenous Peoples in the Russian Federation" should be supplemented with rules regulating the basic forms of co-management including quota allocations, participation in developing and control of research programs (or other strategies), consultation and cooperation with the governments concerning the lands and resources, joint committees or other bodies; 
- it is important to overcome the fragmentation of the legal regulation on participation of indigenous peoples. Comprehensive legal mechanisms should be introduced in special federal laws concerning indigenous peoples - Land Code, Forestry Code, Law "On Territories of Traditional Resource Use";

- to establish a specialized federal body and vest it with the powers to regulate the issues of indigenous peoples with special consideration of the northern indigenous peoples. The main function of this body can be the protection of indigenous peoples' rights and interests, especially in the northern territories; consultations and other cooperation techniques, means to obtain their free and informed consent prior to the approval of any Arctic project affecting indigenous territories and natural resources available to them;

- it is necessary to increase the legal and administrative capabilities of regions and local authorities and vest them with powers to involve indigenous peoples in the management of the northern territories. As a first measure it is necessary to regulate quotas of representation of indigenous peoples in the legislature and municipal representative bodies in the federal legislation, as well as to include provisions on organizing local governments accordingly to the traditional way of life and occupations. Also there is a need to endow the indigenous communities with separate powers of local governments.

In general all Arctic states should try to ensure that the economic interests of the industrial development of the Arctic territories do not get priority over the interests of indigenous peoples who want to preserve their territories of traditional lifestyle and to use the Arctic lands and resources for their sustainable development. These interests must be mutual, and their combination should be provided by governments through the recognition of international principles and standards (such as participation, free, prior and informed consent, co-management). National, regional and local authorities in conjunction with indigenous peoples must make every effort to save the Arctic as the home of the northern indigenous peoples.

\section{References}

Abate, Randall S. and Elizabeth Ann Kronk (eds). 2013. Climate Change and Indigenous Peoples: The Search for Legal Remedies. Cheltenham and Northampton: Edward Elgar Publishing.

Abrams, Peter, Grazia Borrini-Feyerabend, Julia Gardner and Pippa Heylings. 2003. Evaluating Governance: A Handbook to Accompany a Participatory Process for a Protected Area. Report for Parks Canada and CEESP/CMWG/TILCEPA presented at the $5^{\text {th }}$ World Parks Congress, Durban (South Africa), September. 
Abryutina, Larisa, and Valery Chashchin. 2004. "Lifestyle, Social and Economic Status of Indigenous Peoples." In Sulyandzig, a Pavel et al (ed.). Persistent Toxic Substances, Food Security and Indigenous Peoples of the Russian North. Final Report. Oslo: AMAP Secretariat, 20-21. Available at http://www.amap.no/ documents/doc/persistent-toxic-substances-food-security-and-indigenouspeoples-of-the-russian-north.-final-report/795/ (last accessed 31.05.2015).

African Charter for Popular Participation in Development and Transformation. 1990. Adopted at the International Conference on Popular Participation in the Recovery and Development Process in Africa, held in Arusha in 1990. Available at www.un.org (last accessed 22.06.2015).

Agenda 21. 1992. United Nations Conference on Environment \& Development, 3-14 June, Rio de Janerio, Brazil. Available at http://sustainabledevelopment. un.org/content/documents/Agenda21.pdf/ (last accessed 31.05.2015).

Andrichenko, Liudmila. 2005. Regulirovanie i Zaschita Prav Nacionalnyh Menshinstv i Korennyh Malochislennyh Narodov $v$ Rossiikoi Federatsii [Regulating and Protecting the Rights of National Minorities and Indigenous Peoples in the Russian Federation]. PhD diss., Moscow State University. Available at DisserCat. http://www.dissercat.com/content/regulirovanie-i-zashchita-pravnatsionalnykh-menshinstv-i-korennykh-malochislennykh-narodov-/ (last accessed 02.06.2015).

Arctic Info. 2014. Indigenous Peoples of the North. Available at http://www.Arcticinfo.com/Encyclopedia/Rubric/indigenous-peoples-of-the-north (last accessed 03.04.2015).

Arctic Monitoring and Assessment Programme. 2004. Persistent Toxic Substances, Food Security and Indigenous Peoples of the Russian North. Final Report: Arctic Monitoring and Assessment Programme Final Report. Oslo: AMAP Secretariat. Available at http://www.amap.no/documents/doc/persistent-toxicsubstances-food-security-and-indigenous-peoples-of-the-russian-north.final-report/795/ (last accessed 31.05.2015).

Baker, Betsy. 2013. From the Gulf of Mexico to the Beaufort Sea: Inuit Involvement in Offshore Oil and Gas Decisions in Alaska and the Western Canadian. Environmental Law Reporter News \& Analysis. 43, 10925.

Batyanova, E. P., I. V. Bakhmazkaya, I. V. Vlasova and X. P. Poplavskaya 2009. Narody Rossii. Atlas Kultur i Religii [Peoples of Russia. Atlas of Cultures and Religions]. Moscow: Feoria.

Berkes, Fikret, Peter George and Richard J. Preston. 1991. "Co-management." Alternatives 18(2), 12-18. 
Borrini-Feyerabend, Grazia. 1996. Collaborative Management of Protected Areas: Tailoring the Approach to the Context. Gland, Switzerland: IUCN. Available at http://www.iucn.org/themes/spg/Files/tailor.html (last accessed 24.03.2015).

Borrini-Feyerabend, G., M. T. Farvar, J. C. Nguinguiri and V. A. Ndangang. 2000. Co-management of Natural Resources: Organising, Negotiating and Learning by-Doing. Heidelberg, Germany: GTZ, Kasparek. Available at http://nrm. massey.ac.nz/changelinks/cmnr.html (last accessed 03.03.2015, also available in French and Spanish).

Borrini-Feyerabend, Grazia, Michel Pimbert, Taghi M. Farvar, Ashish Kothari and Yves Renard. 2004. In Borrini-Feyerabend, Grazia and Michel Pimbert (ed.). Sharing Power. Learning by Doing in Co-management of Natural Resources Throughout the World. Tehran: IIED and IUCN/CEESP/CMWG, Cenesta: 68.

Borrini-Feyerabend, Grazia and Trevor Sandwith. 2003. "From Guns and Fences to Paternalism to Partnerships: The Slow Disentangling of Africa's Protected Areas." Parks 13(1), 1-5. Available at www.iucn.org/themes/ceesp/Publications/TILCEPA /Editorial-13_1.pdf (last accessed 02.06.2015).

Constitution of the Russian Federation. 2014. SZ RF 31: 4398 Available at http:// www.constitution.ru/en/10003000-04.htm (last accessed 04.03.2015).

Damas, David. 2004. Arctic Migrants/Arctic Villagers: The Transformation of Inuit Settlement in the Central Arctic. Montreal, Quebec, Canada: McGill-Queen's University Press.

Directorate of the UNEP/GEF Russian Federation: Support to the National Program of Action for the Protection of the Arctic Marine Environment. 2009. Environmental Co-Management of Extracting Companies, Authorities and Indigenous Peoples of the North. Moscow: Demonstration Project of the United Nations Environment Programme. The Batani International Development Fund for Indigenous Peoples of the North, Siberia and the Far East: 49-50 Available at http://npa-arctic.iwlearn.org/Documents/demos/old/coman/final_rpt.pdf (last accessed 04.03.2015).

DRIPS. 2007. United Nations Declaration On the Rights of Indigenous Peoples. Available at http://www.un.org/esa/socdev/unpfii/documents/DRIPS_en.pdf (last accessed 13.04.2015).

Federalnyi Zakon [Federal Law] No. 209-FZ. 2009. Ob Ohote i o Sohranenii Ohotnichih Resursov i o Vnesenii Izmenenii v Otdelnye Zakonodatelnye Akty Rossiiskoi Federacii [Hunting and Preservation of Hunting Resources]. SZ RF 30: 3735. 
Federalnyi Zakon [Federal Law] No. 49-FZ. 2001. O Territoriah Tradicionnogo Priridopolzovania Korennyh Malochislennyh Narodov Severa, Sibiri i Dalnego Vostoka Rossiiskoi Federacii [Territories of Traditional Resource Use of the Indigenous Peoples of the North, Siberia and Far East of the Russian Federation]. SZ RF 20: 1972.

Foundations of Russian Federation Policy in the Arctic until 2020 and beyond. 2009. Available at http://icr.Arcticportal.org/index.php?option=com_conten t\&view $=$ article\&id $=1791 \% 253$ (last accessed 02.06.2015).

Fow, Samantha J. 2012. “The Arctic Sustainability Principle". Vermont Journal of Environmental Law 13, 53.

Ghai, Dharam and Jessica M. Vivian (eds). 1992. Grassroots Environmental Action: People's Participation in Sustainable Development. London: Routledge.

Gray, Barbara. 1989. Collaborating: Finding Common Ground in Multiparty Problems. San Francisco/Oxford: Jossey-Bass Publishers.

GRIPRF. Federalnyi Zakon [Federal Law] No. 82-FZ. 1999. O garantiyah prav korennyh malochislennyh narodov Rossiskoi Federatsii [Guarantees of Rights of Indigenous Peoples in the Russian Federation]. SZ RF 18: 2208.

Holland, Jeremy and James Blackburn. 1998. Whose Voice? Participatory Research and Policy Change. London: Intermediate Technology Publications.

Hornstein, Donald T. 1999. "Environmental Sustainability and Environmental Justice at the International Level: Traces of Tension and Traces of Synergy". Duke Environmental Law and Policy Forum Spring. 9, 291.

Indigenous and Tribal Peoples Convention No. 169. 1989. Available at http://www. ilo.org/dyn/normlex/en/f?p=NORMLEXPUB:12100:0::NO::P12100_ILO_ CODE:C169 (last accessed 02.06.2015).

Kharyuchi, Sergei. 2009. "Rol Gosudarstva v Garmonizatsii Promyshlennogo Osvoenia i Ustoichivogo Razvitia Malochislennyh Narodov Severa" [The Role of the Government in Balancing of Industrial Development and Sustainable Development of the Northern Indigenous Peoples]. Mir Korennyh Narodov Zhivaya Arktika [The world of Indigenous Peoples - Live Arctic] 22, 87-90.

Krupnik, Igor. 1993. Arctic Adaptation: Native Whalers and Reindeer Herders of Northern Eurasia. Hanover: UPNE.

Kryazhkov, Vladimir. 2014. "Pravovoe Regulirovanie Otnoshenii Mezhdu Korennymi Malochislennymi Narodami Severa i Nedropolzovatelyami v Rossiiskoi Federatsii" [Legal Regulations of Cooperation Between the Northern Indigenous Peoples and Subsoil Users in the Russian Federation]. Gosudarstvo i Pravo 7, 27-39. Available at www.hse.ru/pubs/share/direct/document/102100720/ (last accessed 03.06.2015). 
Kryazhkov, Vladimir. 2013. "Organy Publichnoi Vlasti i Severnye Narody: Konstitucionno-Pravovye Problemy v Sfere Soupravlenia" [Public Authorities and the Northern Peoples: Constitutional and Legal Issues of Co-Management] In Rudenko, Viktor (ed.). Arkticheskie Regiony Rosii: Problemy Parlamentarisma, Predstavitelstva i Regionalnoi Identichnosti. Ot Rodovyh Obschin $k$ Parlamentu Yamala [The Arctic Regions of Russia: the Problems of Parliamentary System, Representation and Regional Identity. From Tribal Communities to the Yamal Parliament]. Yekaterinburg/Salekhard: Basko.

Lesnoi Kodeks Rossiiskoi Federatsii [Forest Code of the Russian Federation] No. 200-FZ. 2006. SZ RF 50; 5278.

McCay, Bonnie J. and James M. Acheson (eds). 1987. The Question of the Commons. Tucson, Arizona: University of Arizona Press.

NORMLEX. 2015. Information System on International Labour Standards. Available at http://www.ilo.org/dyn/normlex/en/f?p=NORMLEXPUB:11300:0::N O::P11300_INSTRUMENT_ID:312314 (last accessed 02.02.2015).

Osherenko, Gail. 2001. "Indigenous Rights In Russia: Is Title to Land Essential for Cultural Survival?” Georgetown International Environmental Law Review 13, 695.

Park, Eunjung. 2008. "Searching for a Voice: The Indigenous People in Polar Regions." Sustainable Development Law \& Policy 8 (3), 64-65.

Pomeroy, Robert S. and Fikret Berkes. 1997. "Two to Tango: the Role of Government in Fisheries Co-Management." Marine Policy 21(5), 465-480.

Postanovlenie Pravitelstva YANAO [Resolution of the Government of the YamaloNenets Autonomous Area] No. 90-P. 2010. Krasnyi Sever 7, 83.

Rasporyazhenie Pravitelstva RF [Order of the Government of the Russian Federation] No. 132-p. The Concept for the Sustainable Development of Indigenous Peoples of the North, Siberia and the Far East of the Russian Federation. 2009. SZ RF 7, 876.

Rusnak, Gerret. 1997. Co-Management of Natural Resource in Canada: A Review of Concepts and Case Studies. Rural Poverty and Environment Working Paper Series. Ottawa: International Development Research Centre.

Sanford, E. Gaines. 2002. “Triangulating Sustainable Development: International Trade, Environmental Protection, and Development." Environmental Law Reporter 32, 10318-10347.

Shutkin, William A. 1991. "International Human Rights Law and the Earth: The Protection of Indigenous Peoples and the Environment." Virginia Journal of International Law 31, 479. 
Smith, Eric Alden, Joan McCarter and Kurt Engelmann. 1997. Contested Arctic: Indigenous Peoples, Industrial States, and the Circumpolar Environment. Seattle: Russian, East European, and Central Asian Studies Center at the Henry M. Jackson School of International Studies in association with University of Washington Press.

Stevens, Stan (ed.). 2004 [1997]. Conservation through Cultural Survival. Washington, D.C.: Island Press. In Sharing Power: Learning by Doing in Comanagement of Natural Resources throughout the World. Tehran: IIED and IUCN/CEESP/CMWG, Cenesta.

Sulyandziga, Rodion. 2011a. "Princip Svobodnogo, Predvaritelnogo i Osoznannogo Soglasia - Eto To, k Chemu My Dolzhny Stremitsya v Partnerstve s Gosudarstvom" [The Principle of Free, Prior and Informed Consent is the Objective We Have to Follow in the Cooperation with the Government]. Mir Korennyh Narodov: Zhivaya Arktika [The world of Indigenous Peoples: Live Arctic] 27: 4.

Sulyandziga, Rodion. 2011b. "Russian Association of Indigenous Peoples of the North (RAIPON)." Paper presented at UN Permanent Forum on indigenous issues X Session, Agenda item 3, 7 May. Available at http://raipon1.nichost. ru/Documenty/Doklady/PF_NY_2011.doc (last accessed 02.06.2015).

Towards a New Millennium. 2002. Ten Years of the Indigenous Movements in Russia. Copenhagen: IWGIA.

Turpel, Mary E. 1992. “Indigenous Peoples' Rights of Political and Self-Determination: Recent International Legal Developments and the Continuing Struggle for Recognition." Cornell International Law Journal 25, 579.

UNRISD 1979. Participation Programme - A glance at the past and directions for the future, United Nations Research Institute for Social Development, Geneva (Switzerland), United Nations Research Institute for Social Development.

Ustav Chukotskogo Avtonomnogo Okruga [Charter of the Chukotka Autonomous Area ] No. 26-O. 1997. Web-page of the Constitution of the Russian Federation. Available online at http://constitution.garant.ru/region/ustav_chukot/ (last accessed 02.06.2015).

Ustav (Osnovnoi Zakon) Khanty-Mansiiskogo Avtonommnogo Okruga - Yugry [Charter of the Khanty-Mansi Autonomous Area - Yugra] No. 4-oz. 1995. Novosti Yugry 44. 23 April 2005.

Ustav (Osnovnoi Zakon) Yamalo-Nenetskogo Avtonomnogo Okruga [Charter of the Yamalo-Nenets Autonomous Area] No. 56-ZAO. 1998. Krasnyi Sever 44/1 (special edition № 22): 2008. 
Ustav Sakhalinskoi Oblasti [Charter of the Sakhalin Region]. 2001. Official Internet Agency of the Sakhalin Regional Duma, 9 July, 270. Available at http://www. dumasakhalin.ru/documents/region-regulations/article68 (last accessed 02.06.2015).

Vodnyi Kodeks Rossiiskoi Federatsii [Water Code of the Russian Federation] No. 74-FZ. 2006. SZ RF 23: 2381.

World Bank, 1996. The World Bank Participatory Sourcebook, World Bank, Washington D.C.: Library of Congress Cataloging-in-Publication Data.

Yarovoy, Gleb, Sergunin, Alexander, and Lassi Heininen. 2013. Russia's Policy Toward the Indigenous Peoples of the North. Valdai, Discussion Club. Available at http://valdaiclub.com/culture/61780.html/ (last accessed 03.04.2015).

Zakon KHMAO [Law of the Khanty-Mansi Autonomous Area - Yugra] No. 76oz. 2001. O Dume Khanty-Mansiiskogo Avtonomnogo Okruga [On the Duma of the Khanty-Mansi Autonomous Area - Yugra]. Sobranie Zakonodatelstva Khanty-Mansiiskogo Avtonomnogo Okruga, 2001, 10: 1235.

Zakon Respubliki Sakha (Yakutia) [Law of the Republic of Sakha (Yakutia)] No. 349-III. 2004. O Mestnom Samoupravlenii v Respubliki Sakha (Yakutia) [On Local Government in the Republic of Sakha (Yakutia)]. Official web-portal of the Republic of Sakha (Yakutia). Available at http://sakha.gov.ru/node/17816/ (last accessed 02.06.2015).

Zakon Sakhalinskoi Oblasti [Law of the Sakhalin Region] No. 463. 2003. "O Predstavitele Korennyh Malochislennyh Narodov Severa pri Sakhalinskoi Oblastnoi Dume" [On the Representative from Indigenous Small-Numbered People in the Sakhalin Regional Duma]. Internet-Journal of V. C. Levonevski. Available at http://pravo.levonevsky.org/bazazru/texts09/txt09172.htm/ (last accessed 02.06.2015).

Zakon YANAO [Law of the Yamalo-Nenets Autonomous Area] No. 49-ZAO. 2006. O Zaschite Iskonnoi Sredy Obitania i Traditionnogo Obraza Zhizni Korennyh Malochislennyh Narodov Severa $v$ Yamalo-Nenetskom Avtonomnom Okruge [On Protection of Traditional Habitat and Traditional Lifestyle of the Northern Indigenous Peoples in the Yamalo-Nenets Autonomous Area]. Krasnyi Sever 119/1 (special edition 73-74): 2006. 
Zakon YANAO [Law of the Yamalo-Nenets Autonomous Area] No. 114-ZAO. 2005. O Gosudarstvennoi Podderzhke Obschin Korennyh Malochislennyh Narodov Severa i Organizatsyi, Osuschestvlyauschih Vidy Tradicionnoi Hozyastvennoi Deyatelnosti na Territorii Yamalo-Nenetskogo Avtonomnogo Okruga [On State Support to the Communities of Indigenous Peoples of the North and the Organizations Involved in Traditional Occupations in the Territory of the Yamalo-Nenets Autonomous Area]. Vedomosti Gosudarstvennoi Dumy Yamalo-Nenetskogo Avtonomnogo Okruga 11/2, December 2005.

Zakon YANAO [Law of the Yamalo-Nenets Autonomous Area] No. 46-ZAO. 1998. $\mathrm{Ob}$ Olenevodstve [On Reindeer Breeding]. Vedomosti Gosudarstvennoi Dumy Yamalo-Nenetskogo Avtonomnogo Okruga 8, October 1998.

Zemelnyi Kodeks Rossiiskoi Federatsii [Land Code of the Russian Federation] No. 136-FZ. 2001. SZ RF 44: 4147. 